\title{
Is teaching how to suggest a good suggestion? An empirical study based on EFL learners' accuracy and appropriateness when making suggestions ${ }^{1}$
}

\author{
Ana Fernández Guerra \\ Alicia Martínez-Flor \\ Universitat Jaume I
}

Received: 20 March 2005 / Accepted version: 29 August 2005

ISSN: 1697-7467

\begin{abstract}
This paper focuses on the role of foreign language classroom instruction and the effectiveness of an explicit teaching of pragmatic aspects, such as the speech act of 'suggesting', to improve learners' grammatical accuracy and pragmatic appropriateness. Two are the main objectives: (1) to analyse the amount and type of suggestions used by EFL learners, as well as the grammatical mistakes they make; and (2) to ascertain whether learners receiving some sort of formal instruction on appropriate speech act forms or structures will improve their linguistic and pragmatic competence.

Key Words: teaching, pragmatic competence, speech acts, suggestions.

RESUMEN: Este artículo se centra en el papel de la instrucción en el aula de lenguas extranjeras y en la efectividad que puede tener la enseñanza explícita de aspectos pragmáticos, como el acto de habla de la 'sugerencia', a la hora de mejorar la corrección gramatical y la adecuación pragmática de los alumnos. Dos son los objetivos principales: (1) analizar la cantidad y el tipo de sugerencias que utilizan los estudiantes de inglés y los errores gramaticales que cometen; y (2) comprobar si los alumnos que reciben algún tipo de instrucción formal sobre formas o estructuras apropiadas para actos de habla mejoran su competencia lingüística y pragmática.
\end{abstract}

Palabras clave: enseñanza, competencia pragmática, actos de habla, sugerencias.

\section{INTRODUCTION}

Developing learners' pragmatic appropriateness has become nowadays one of the main goals in the English as a Foreign Language (EFL) classroom (Kasper, 2001a, 2001b) and many researchers are now being concerned with the 'teachability' of different pragmatic aspects, such as discourse markers, pragmatic routines, pragmatic fluency, the comprehension of implicature, and various speech acts (see Rose and Kasper, 2001; and Martínez-Flor, Usó

${ }^{1}$ This study is part of a research project funded by (a) the Spanish Ministerio de Educación y Ciencia (HUM2004-04435/FILO), co-funded by FEDER, and (b) Fundació Universitat Jaume I and Caixa Castell óBancaixa (P1.1B2004-34). 
Juan and Fernández Guerra, 2003 for a review). This study focuses precisely on the speech act of suggesting. Actually, the number of suggestions we hear in everyday conversations seems to be countless. However, the number of studies dealing with this speech act and its 'teachability' in an EFL context is certainly limited. We have, thus, decided to deepen on the role of instruction and its advantages (or disadvantages) on learners' acquisition and use of this speech $\mathrm{act}^{2}$. In order to do so, we will compare the amount and type of suggestions they make with and without an explicit instructional approach and try to determine whether teaching pragmatic aspects, such as suggesting, can improve learners' pragmatic appropriateness and their grammatical accuracy. Before discussing the results obtained, however, we will offer a very brief review of some of the theoretical grounds upon which the present study is built, namely research regarding instruction of different pragmatic aspects, and research on the speech act we are dealing with here.

\section{Teaching pragmatic aspects to develop learners' Pragmatic COMPETENCE}

Trying to get EFL learners to use the target language effectively in different and varied contexts has recently gained a great deal of weight. A good number of researchers highlight the importance of developing learners' pragmatic competence and their appropriate use of language (see Bardovi-Harlig and Hartford, 1996; Celce-Murcia, Dörnyei and Thurrell, 1995; Alcón, 2000; or Kasper, 2001a, 2001b, amongst others). Indeed, FL learners often misuse or are not aware of certain language forms that are socially and culturally appropriate in the target language community, and this fact can often lead to pragmatic failure (Thomas, 1983).

Which is, then, the role of instruction in developing learners' pragmatic competence? Can (or should) we actually teach our learners how to use pragmatic strategies appropriately? These questions still seem to be a matter of debate. On the one hand, some researchers assume that pragmatic competence develops alongside lexical and grammatical knowledge, or that this knowledge is already in our learners' mind (be it because some pragmatic knowledge is universal, or because some pragmatic aspects are successfully transferred from a native language), and that, therefore, no instruction is needed (see Kasper, 1997; Kasper and Schmidt 1996; or Kasper and Rose, 2001, for example). In many other studies, on the other hand, pragmatic instruction (whether explicit or implicit) has proven to be useful. Quoting Kasper (1997), "formal instruction of the selected pragmatic features is advantageous; explicit instruction is more effective than implicit; instruction benefits not only advanced students, but also beginners". Moreover, acquiring pragmatic competence often requires some sort of pedagogic intervention, especially in those cases in which one must be aware of social norms, linguistic routines, directness and politeness values in the target community (Kasper, 1997; Judd, 1999; Bardovi-Harlig, 2001; Kasper and Rose, 2002, etc.). As Judd (1999: 154) affirms, "instruction in pragmatic skills needs to be carried out formally, as part of the regular content in second language curricula".

\footnotetext{
${ }^{2}$ A different, but interrelated, study on the matter has also been carried out, focusing on the role of teachers' feedback and the role of collaborative discourse to develop learners' pragmatic competence when making suggestions in the EFL classroom (see Martínez-Flor and Fernández Guerra, forthcoming)'.
} 
Bearing this in mind, numerous studies are now being devoted to examining the influence of instruction, the different types of instructional approaches, their length, the need for appropriate and contextualised input, the necessary opportunities for practice, the pragmatic aspects that can be taught, etc. (for more information in any of these features, see Kasper, 1997; Norris and Ortega, 2000; and the volumes edited by Rose and Kasper, 2001 or by Martínez-Flor, Usó Juan and Fernández Guerra, 2003). In spite of this, more research still needs to be carried out on the field. Kasper and Rose (2001: 4-9) suggest three areas that need to be expanded to a great extent: (i) classroom-based interlanguage pragmatics research, to examine the opportunities for developing pragmatics that are offered in language classrooms; (ii) interlanguage pragmatics research, to prove or disprove whether pragmatic ability develops in classroom setting without explicit instruction; and (iii) classroom research, to focus on the effects that various approaches to instruction have on pragmatic development.

Some of the main studies carried out so far dealing with pragmatic instruction in a FL are outlined in Table 1. As can be seen, a great deal of interlanguage pragmatics research has been done on specific and, sometimes, isolated aspects, such as speech acts. This is an indicative of the fact that the use of speech acts is a central issue in pragmatics. CelceMurcia et al. (1995: 9), for instance, referred to pragmatic competence as actional competence, and defined it as "competence in conveying and understanding communicative intent by performing and interpreting speech acts and speech act sets". All these studies also show the enhanced importance attached to the presentation of speech acts in classroom materials or conversations, and also to the teaching of (or raising awareness on) speech act sets in the FL classroom (Olshtain and Cohen, 1991: 155).

Table 1. Studies examining the effect of pragmatic instruction (quoted from Martinez-Flor 2004):

\begin{tabular}{|ll|}
\hline Pragmatic feature analysed & Interventional studies carried out \\
\hline Discourse markers and strategies & House and Kasper (1981), Yoshimi (2001) \\
\hline Pragmatic routines & $\begin{array}{l}\text { Wildner-Bassett }(1984,1986,1994), \text { Tateyama et al. } \\
\text { (1997), Tateyama (2001) }\end{array}$ \\
\hline Pragmatic fluency & House (1996) \\
\hline Implicatures & Bouton (1994), Kubota (1995) \\
\hline Sociostylistic variation & Lyster (1994) \\
\hline Interactional norms & Liddicoat and Crozet (2001) \\
\hline Hedges in academic writing & Wishnoff (2000) \\
\hline Sociopragmatics in requesting & Fukuya et al. (1998) \\
\hline Mitigators in requests & $\begin{array}{l}\text { Fukuya (1998), Fukuya and Clark (2001), Safont } \\
\text { (2001, 2003) }\end{array}$ \\
\hline Politeness/indirectness in requesting & LoCastro (1997), Salazar (2003) \\
\hline Compliments & Billmyer (1990), Rose and Ng Kwai-fun (2001) \\
\hline Requests & $\begin{array}{l}\text { Alcón and Safont (2001), Safont (2003), Takahashi } \\
\text { (2001) Fukuya and Zhang (2002) }\end{array}$ \\
\hline Apologies & Olshtain and Cohen (1990) \\
\hline Complaints & Morrow (1995), Shaw and Trosborg (2000) \\
\hline Refusals & Morrow (1995) \\
\hline
\end{tabular}




\section{Teaching how to SUggest}

An inappropriate use of speech acts realisation strategies can certainly give rise to a good number of misunderstandings; however, getting students to use speech acts accurately and appropriately in the FL is not an easy task. Most of the research mentioned above can shed light on how FL teachers can make instruction on speech acts more effective, but 'suggesting' has received scant attention in interlanguage pragmatic studies. This means that there are very few suggestions on how to teach 'suggestions'.

In order to describe suggestions, we should start mentioning that they are directive and exhortative speech acts, in which the speaker wants someone to do something (Martínez-Flor and Fernández Guerra, forthcoming). Yet, as opposed to other directive speech acts, such as requests, for example, they are non-impositive speech acts (Haverkate, 1984), which means that the speaker is not demanding or imposing anything, and that the benefits of the act are exclusively for the hearer. Taking this assumption into consideration, and in line with previous studies (Banerjee and Carrell, 1988; Hinkel, 1994, 1997; Mandala, 1999; Koester, 2002), we have regarded non-inclusive suggestions and advice as the same speech act, because the linguistic formulae used in both of them are quite similar. Notwithstanding, the speech act of suggesting, being an exhortative speech act, involves some threat to the listener, since s/he might not be sure of the speaker's true intentions when performing the suggestion. In this sense, suggesting is a face-threatening act to the listener (Brown and Levinson, 1987), because the speaker is in some way intruding the hearer's world by performing an act about what the latter should do. Given this situation, the speaker shall try to minimise to the greatest extent the possibility that the listener might be offended by softening the speech act through the use of certain mitigation devices and through indirect strategies. In other words, making an accurate and appropriate suggestion requires a high level of pragmatic competence.

Table 2 displays the main conventional expressions or strategies used by native speakers of English when making suggestions in very different contexts. The typology shown here is based on previous studies within the area of interlanguage pragmatics that have focused on suggestions (Alcón and Safont, 2001; Banerjee and Carrell, 1988; Bardovi-Harlig and Hartford, 1996; Beebe et al., 1990; Hinkel, 1994, 1997; Kasper and Schmidt, 1996; Koike, 1994, 1996; Schmidt et al., 1996; Wardhaugh, 1985). 
Table 2. Types of suggestions

(extracted from Martínez-Flor \& Fernández Guerra, forthcoming).

\begin{tabular}{|l|ll|}
\hline \multicolumn{2}{|l}{ Type } & \multicolumn{2}{l}{ Strategy } & Example \\
\hline \multirow{2}{*}{$\begin{array}{l}\text { Direct } \\
\text { suggestion }\end{array}$} & Performative verb & I suggest that you ..., My advice would be ... \\
\cline { 2 - 3 } & Imperative & Try using ... \\
\hline \multirow{4}{*}{$\begin{array}{l}\text { Conven- } \\
\text { tionalised } \\
\text { forms }\end{array}$} & $\begin{array}{l}\text { Specific formulae } \\
\text { (interrogative forms) }\end{array}$ & Why don't you ...?, How about ...?, What about ...? \\
\cline { 2 - 3 } & Possibility/probability & You can/could ,... You may/might ... \\
\cline { 2 - 3 } & Should /ought to & You should ..., you ought to... \\
\cline { 2 - 3 } & Conditional & If I were you, I would ... \\
\cline { 2 - 3 } & Need & You need to ... \\
\cline { 2 - 3 } & Recommend & I recommend you ... \\
\hline \multirow{2}{*}{$\begin{array}{l}\text { Indirect } \\
\text { suggestions }\end{array}$} & Impersonal sentences & It would be a good idea to ...; It would be better to .... \\
\hline
\end{tabular}

Regarding the possibilities in which we can present and practice the speech act in an instructional setting, the following teaching techniques, proposed by Olshtain and Cohen (1991: 160-162) to focus on apologies, can also be very useful to make learners become aware of the cross-cultural differences in the realisation strategies of all speech acts:

- Assessing our learners' level of awareness of the speech act to be taught.

- Presenting examples of the speech act as actualised in real-life situations, so that they become aware of the linguistic, situational, and social factor as compared to their native language.

- Reinforcing learners' awareness of all the factors affecting the choice of different strategies in different situation.

- Practising the use of the speech act in real-world (hypothetical) situations.

- Discussing and providing feedback on their expectations, perceptions, etc. of the target language speech act behaviour.

Needless to say, an accurate and appropriate use of suggestion strategies should take into account both (1) our learners' linguistic proficiency and (2) their pragmatic awareness and appropriate use of this speech act. Along with the studies that have just been reviewed, we can assume that learners will produce more accurate and more pragmatically appropriate suggestions when receiving instruction on speech acts. Accordingly, the hypotheses underlying this empirical study are:

(1) Learners receiving instruction will use more varied and more pragmatically appropriate realisation strategies when suggesting.

(2) Learners receiving instruction will improve their grammatical accuracy when suggesting. 
In order to confirm these assumptions, we have first counted the grammatical mistakes made by students when making suggestions and observed whether learners receiving instruction made less mistakes. Then, we have analysed the main strategies used for suggesting, and compared whether receiving or not some instruction on the use of speech acts makes a difference in their use of pragmatically appropriate suggestions.

\section{Methodology}

\subsection{Participants and procedure}

To ascertain that instruction of pragmatic aspects in the EFL classroom can be useful, we have carried out an experiment involving 75 learners studying a Teacher degree (Magisterio de educación infantil) at the Universitat Jaume I, in Castellón. Their profile is the following: participants were attending an English Language compulsory subject and, according to a proficiency test administered at the beginning of the course, all of them were at the beginner or lower-intermediate level. Out of those 75 students, only 6 of them were males. Most of them were 18 or 19 years old, except 4 women over 35 .

The students in this English module were originally divided into two groups (PR1 and PR2), and consequently attended two different classes. In order to see whether our FL learners benefit from instruction, at least when making suggestions, we 'taught' how to suggest things to one of the groups but not to the other:

- Group PR1, consisting of 34 students, received instruction on the main strategies used when suggesting and on how the use of those linguistic forms can vary depending on different social contexts. We decided to devote a 3-week instruction period (a total of 6 hours) to the teaching of 'suggestions', since we thought that it would be enough to improve our learners' ability to use language appropriately and accurately when suggesting something to their peers and their teacher. Learners in this group also received classroom input with real-world examples of suggestions and an extensive list of strategies they could use when making all sorts of suggestions, in formal, general and informal contexts. Besides, the teacher solved all problems that arose while completing the activities ${ }^{3}$.

- Group PR2 was composed of 41 students that were not provided with any instruction concerning speech acts, neither explicit nor implicit, and no teacher's feedback on the linguistic forms they used.

This English course was of a practical nature and provided learners with many opportunities to use the target language. In the last five weeks ${ }^{4}$, learners had to do a role-play presenting

${ }^{3}$ Students in this group did not only receive teachers' feedback when required (mainly on the vocabulary and the linguistic forms they employed), but they also worked in pairs, which can also make a difference in their performance of suggestions, as shown in a previous study (Martínez Flor and Fernández Guerra, forthcoming).

${ }^{4}$ For the purpose of this study, we have only taken into account the last three sessions of the course, since the performance of our students in group PR1 could not be analysed before the pedagogical intervention. 
a class activity designed for teaching English to children (incorporating appropriate activities for little kids, such as singing, dancing, jumping, rhythmical clapping, verbal repetitions, finger puppets, flashcards, directed body movements, drawing, etc...). After each learner presented the activity s/he had planned, the rest of the students were asked to provide different suggestions on the activity, the materials used and the teaching ideas. These suggestions could be done either to the real lecturer of the course or to their peers, or even to pre-school and primary school teachers in general, since they played the role of a teacher when presenting the activities they planned. In other words, they were the ones that specified the social distance (Brown and Levinson, 1987), depending on the person they addressed in their suggestions.

All these suggestions comprised the corpus of the present study, in which we analysed: (1) the amount and kind of linguistic forms learners employed when making suggestions and (2) whether being involved in instructional sessions helped them in their use of both correct and appropriate written suggestions.

\subsection{Coding and analysis of the data}

The method we followed to code and analyse the data consisted of marking every suggestion learners provided and all the grammatical mistakes made, taking into account the appropriateness and the elaborateness or complexity of their suggestion. We followed the taxonomy reproduced in Table 2, and classified their suggestions into direct, conventionalised, and indirect suggestions. Moreover, when trying to deeply examine their use of the speech act of suggesting, other categories were also added, so as to include more structures or strategies that learners employed quite often in their suggestions, as well as their use of mitigating devices. These additional categories are gathered in Table 3.

Table 3. Additional aspects analysed in the present study

\begin{tabular}{|l|l|}
\hline \multicolumn{2}{|c|}{ New types of suggestions } \\
\hline \multirow{3}{*}{$\begin{array}{l}\text { Inclusive } \\
\text { 'we' }\end{array}$} & $\begin{array}{l}\text { Linguistic expressions using we when suggesting something that the other } \\
\text { interlocutor could do ('We could do...', 'We need...', 'We might...', 'Shall we...?', } \\
\text { 'Let's', etc.). }\end{array}$ \\
\hline \multirow{5}{*}{$\begin{array}{l}\text { Other } \\
\text { formulae }\end{array}$} & $\begin{array}{l}\text { Expressing obligation by saying 'You must...' and 'You have to...'. } \\
\text { keen on...', 'I prefer...', 'I really like/enjoy/love...', etc.) as a way of suggesting } \\
\text { something implicitly. }\end{array}$ \\
\cline { 2 - 3 } & $\begin{array}{l}\text { Just giving the suggestion, without using any structure for suggesting, such as 'A } \\
\text { song', to suggest that it would be a good idea to include a song in the activity. }\end{array}$ \\
\cline { 2 - 3 } & $\begin{array}{l}\text { Not giving a suggestion, by saying something like 'I don't know what to say', 'It's } \\
\text { hard/difficult to say', etc. }\end{array}$ \\
\hline \multirow{5}{*}{$\begin{array}{l}\text { Down- } \\
\text { graders \& } \\
\text { grounders }\end{array}$} & $\begin{array}{l}\text { Suggestions softened by internal modification devices: showing personal opinion (I } \\
\text { think..., In my opinion..., From my point of view..., The way I see it..., etc.) using } \\
\text { softening devices (perhaps, maybe, probably, etc.). }\end{array}$ \\
\cline { 2 - 3 } & $\begin{array}{l}\text { Using external modification devices: giving explanations when making the } \\
\text { suggestion (for example, 'The activity was very difficult because there was a lot of } \\
\text { new vocabulary', suggesting that the activity should include less vocabulary). }\end{array}$ \\
\hline
\end{tabular}




\section{Results OF THE STUDY}

The results of this study are divided into two different sections, in which we discuss the issues of pragmatic appropriateness and grammatical accuracy separately, but the issue of receiving or not instruction is treated jointly in each section, so as to be able to compare whether pedagogical intervention on how to suggest makes learners in group PR1 (1) use more varied and more pragmatically appropriate realisation strategies when suggesting, and, at the same time, (2) improve their grammatical accuracy when suggesting.

\subsection{The role of instruction in developing learners' pragmatic appropriateness when suggesting}

As mentioned above, one of our aims was to analyse both the amount and type of suggestion realisation strategies produced by students in both groups PR1 and PR2 (i.e. learners receiving instruction and learners that did not receive any instruction on suggestions), in order to find out whether this difference had an effect on learners' acquisition and production of the speech act. Figure 1 shows the frequency of the types of suggestions used by learners in both groups, classified into the main categories of direct suggestions, indirect suggestions, conventionalised forms, and non-conventional forms such as the use of inclusive 'we' and other formulae (as presented in Tables 2 and 3). As can be noticed in the chart, both groups behaved rather similarly in the amount of strategies they made use of when expressing suggestions. As regards the quantity of suggestions employed, thus, the preliminary findings drawn from these results do not reveal any significant differences between both approaches. In fact, the only slight difference seems to be in the use of direct strategies for suggesting.

Figure 1. Types of suggestions used by learners.

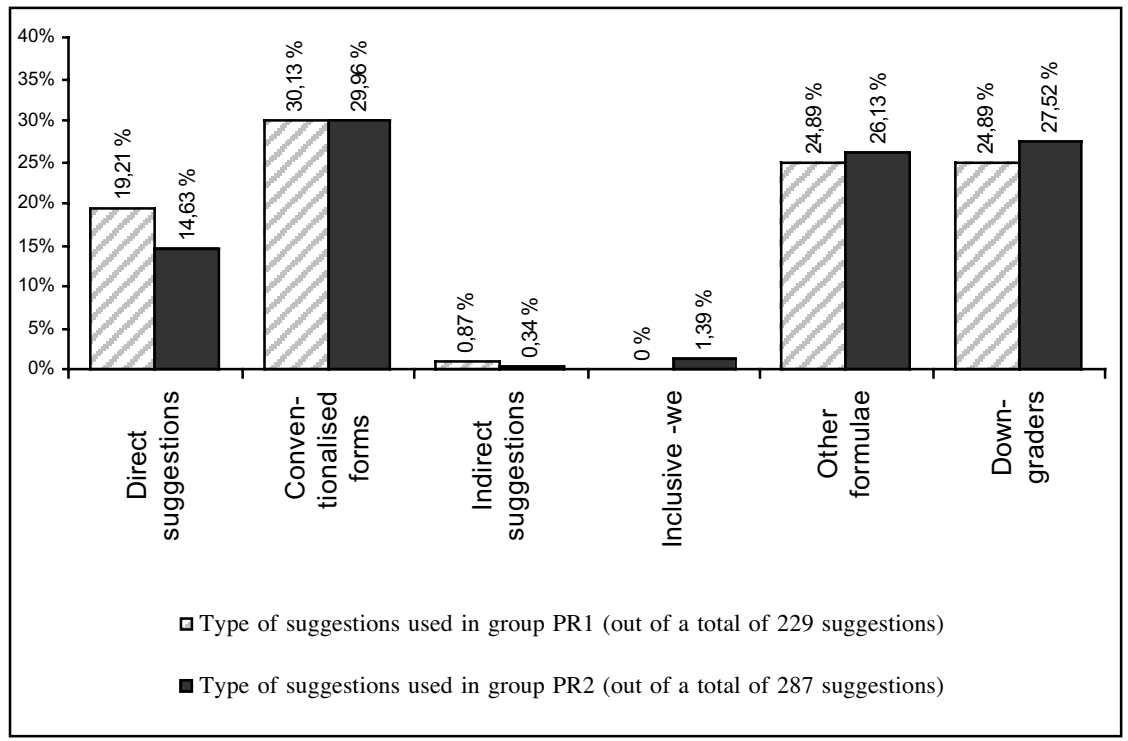


Nonetheless, adopting a qualitative analysis of all suggestions, some substantial differences can be observed. Starting with their use of 'direct strategies', and although learners in group PR1 used more direct suggestions (a total of 23 imperatives and 21 performative verbs out of 229) than learners in group PR2 (25 occurrences of imperatives and 17 performatives out of a total of 287 suggestions), they also employed more varied verbs, probably due to all the examples they had in the list of strategies they received:

I'd like to propose a song.

We suggest to do plays with all the concepts.

I would recommend that they must improve their body contact.

My advice would be to sing more songs.

Moving on to the 'conventionalised linguistic forms' of the suggestions made, Figure 1 shows that learners clearly tend to use these forms; but we think that measuring all their realisation strategies can be illustrating. To start with, none of the students used interrogative forms (such as 'Why don't you do this?', for example, which is said to be quite common in real-world suggestions) or the verb 'need', and only one student in group PR2 used a form with 'I recommend you...'. In contrast, a high percentage of the other strategies considered as rather conventionalised (i.e. can/could, should and conditionals) was used by students in both groups. Suggestions with can/could... accounted for 25 occurrences in PR1 $(10.91 \%$ of the suggestions in group PR1) and 29 occurrences in PR2 (10.10\%). Should/ought to appeared 23 times in PR1 (10.04\%) and 37 times in PR2 (12.89\%). Conditionals were used in 21 occasions by PR1 (9.17\%) and in 19 by PR2 (6.62\%). This over-use of modal verbs and conditionals can be explained because they are important grammatical points in students' syllabi at High School, and learners, independently from the group they belong to, have made use of the structures they already knew. These are some examples of conventionalised forms from students in both groups:

They could be explain the song very clearly.

They could have brought some real food to eat and taught us about it.

Perhaps they should said the meaning of the word «sentence».

I think they should be a little bit more expressive...

If I were him, I would work with drawings because...

I would repeat vocabulary more times.

'Indirect suggestions', on the other hand, were very low in frequency: there were only 2 suggestions starting with 'It would be better to ...' in PR1 and 1 suggestion in PR2. This is somehow surprising, since students in group PR1 received input in which impersonal forms were very often employed by English native speakers.

As regards 'inclusive-we', there were only 4 cases within PR2:

We could write the name of the number.

We should read a story about these letters.

We should work more about the numbers.

We need include more materials. 
One realises that using 'we' to suggest something to someone else is not very common in English; yet we were interested on whether our participants employed linguistic expressions involving both hearer and speaker. Learners' low use of the pronoun we may have been due to the fact that they had to write down their suggestions and hand them in to the teacher, which could push them to express non-inclusive suggestions, given the fact that they were not giving the suggestion directly to their classmates and, hence, their suggestions showed benefits exclusively for the students' presentations.

'Other formulae' accounted for $24.89 \%$ of the overall suggestions made by group PR1 and $26.13 \%$ by PR2. A close examination of the strategies used within this category does only indicate different effects between learners that were taught how to suggest and those that were not under instructional sessions in the case of verbs indicating obligation. The counting is the following:

Obligation (you must... and you have to...): 7 suggestions in PR1 and 20 in PR2.

Expressing likes and dislikes (I liked..., I enjoyed..., etc.): 12 suggestions in PR1 and 14 in PR2.

Just giving the suggestion: 3 suggestions in PR1 and 5 in PR2.

Not giving an opinion or not offering any suggestion: 35 in PR1 and 36 in PR2.

The over-use of certain structures mentioned before, as regards 'conventionalised forms', is also the case with the modal must, which is said to be inappropriate when suggesting. Learners in group PR2 used 'obligation' too often (there are 17 instances of you must and 3 instances of you have to). The examples below, taken from PR2, can give an idea about this abusive use of the verb 'must':

I think that they must introduced new vocabulary.

You must use the pronunciation slow.

The activity must be more funny.

They must give less handouts.

Expressing likes and dislikes can also be considered as a suggestion, as in the cases reproduced below. In PR1, though, we expected to find more occurrences of this kind of implicit suggestion, because they received instruction on many ways that are used to express likes, approval, preference, disapproval, etc. in many different situations. But they only followed three of the expressions they were given in the instructional period:

\section{Group PRI}

Dancing doesn't appeal to me very much.

Drawing is much more interesting than writing.

We disapprove of writing a lot for children activity.

\section{Group PR2}

Yes, my suggestion is that I like working in reduced groups.

The activities have been a few bored.

I think that everything was very fine. 
In some other cases ( 3 in PR1 and 5 in PR2), students produced "false" suggestions, since they just gave the suggestion, without any preceding phrase or structure:

More exercises and more speak in English the new words.

The alphabet in English.

More repetitions.

Learners (both in PR1 and PR2) also avoided providing suggestions very often (in 35 and 36 suggestions, respectively). The big difference here lies in the kind of strategies used, since learners in PR1 were given a list that included several examples of ways to avoid providing suggestions:

\section{Group PRI}

I'd rather not say.

We don't know what to say because all the lesson was terrific.

I don't hold any particular view on the matter so I can't say.

\section{Group PR2}

No, I don't want to comment.

I'm nothing suggestion.

I don't have suggestions.

Finally, learners' use of peripheral modification devices was also considered, as mitigators can have an effect on the pragmatic production of suggestions, making the speech act become more appropriate in certain situations. The overall amount of 'downgraders and grounders', as presented in Figure 1, is basically the same in both approaches followed. Still, the expressions used in PR1 are, again, significantly more appropriate than those used by students in PR2, since they can make suggestions less authoritative. Group PR1 had 42 downgraders, using a wider variety of mitigating phrases and more grammatically correct sentences; whereas group PR2 used 57 downgraders, having recourse to 'I think' most of the times:

\section{Downgraders by group PRI}

From my point of view, the teachers could include more activities.

Maybe they could play a song because kids like it very much.

I think that they should be a little bit more expressive and that....

\section{Downgraders by group PR2}

I think that the teachers must be do more repetitions with the clothes.

I think the teachers must used the pronunciation slow.

I think that they must be do less handouts.

I think they ought to speak happierly.

Additionally, there were 15 instances of grounders in PR1 and 22 in PR2. By means of these grounders, learners gave reasons or explanations to imply a hidden suggestion, as a way of softening the force of the speech act: 
The lesson was difficult because there were a lot of handouts. (PR1)

The teacher have been speak too fast and should ... (PR2)

To sum up, even if differences between both groups (in the amount and typology of suggestions produced) are not quantitatively significant, when it comes to pragmatic production of suggestions, receiving instruction appears to have a positive effect in developing learners pragmatic appropriateness. Actually, the main difference between the results obtained with the two approaches lies on the variety of strategies used within each of those six main categories of conveying suggestions. Overall, it may be claimed that there is evidence that teaching learners how to use more appropriate forms to make suggestions and raising their awareness of the devices that can soften the impact of this speech act can be especially useful in their acquisition and production of pragmatic aspects.

These findings make us assume, in line with Kasper (2001a, 2001b) and Bardovi-Harlig (2001), that pragmatic instruction in the EFL classroom is really necessary for the acquisition of pragmatic competence. However, the differences we have presented in this section are not substantial enough to wholly support our first hypothesis. The reasons for this may be learners' limited linguistic resources and the length of the instructional period: on the one hand, their linguistic competence might not have yet risen to the required level to appreciate crosscultural differences in pragmatic features; and on the other hand, the instruction might not have been enough to make them completely aware of all the pragmatic aspects involved on how we use the language and, therefore, to improve their ability to use suggestions appropriately.

\subsection{The role of instruction in developing learners' grammatical accuracy when suggesting}

The next concern dealt with our learners' linguistic proficiency and whether explicit classroom intervention on the speech act of suggesting could help learners improve their grammatical accuracy when making suggestions. Figure 2 shows the grammatical mistakes made in students' use of this speech act.

Group PR1 only had 29 ungrammatical utterances (a 12.66\% of the suggestions analysed for this study), whereas group PR2 produced 68 ungrammatical utterances $(23.7 \%)$. This percentage clearly indicates that there are more grammatical mistakes in the expressions used for suggesting when students are not provided with explicit instruction on the issue. Let us see some examples of the mistakes made by learners in PR2, classified into the same suggestion types we followed in the previous section (four of the suggestions shown before are reproduced here for convenience):

\section{Direct suggestions}

My suggestion is realise more activities.

Work on more difficult handouts.

Not work so fast.

\section{Conventionalised forms}

They could to teach the time.

They could practiced more vocabulary.

The poem should been writte more big in the blackboard.

She shoulded use more material and more activities that we could participate. 
Figure 2. Grammatical mistakes made with (PR1) and without (PR2) instruction.

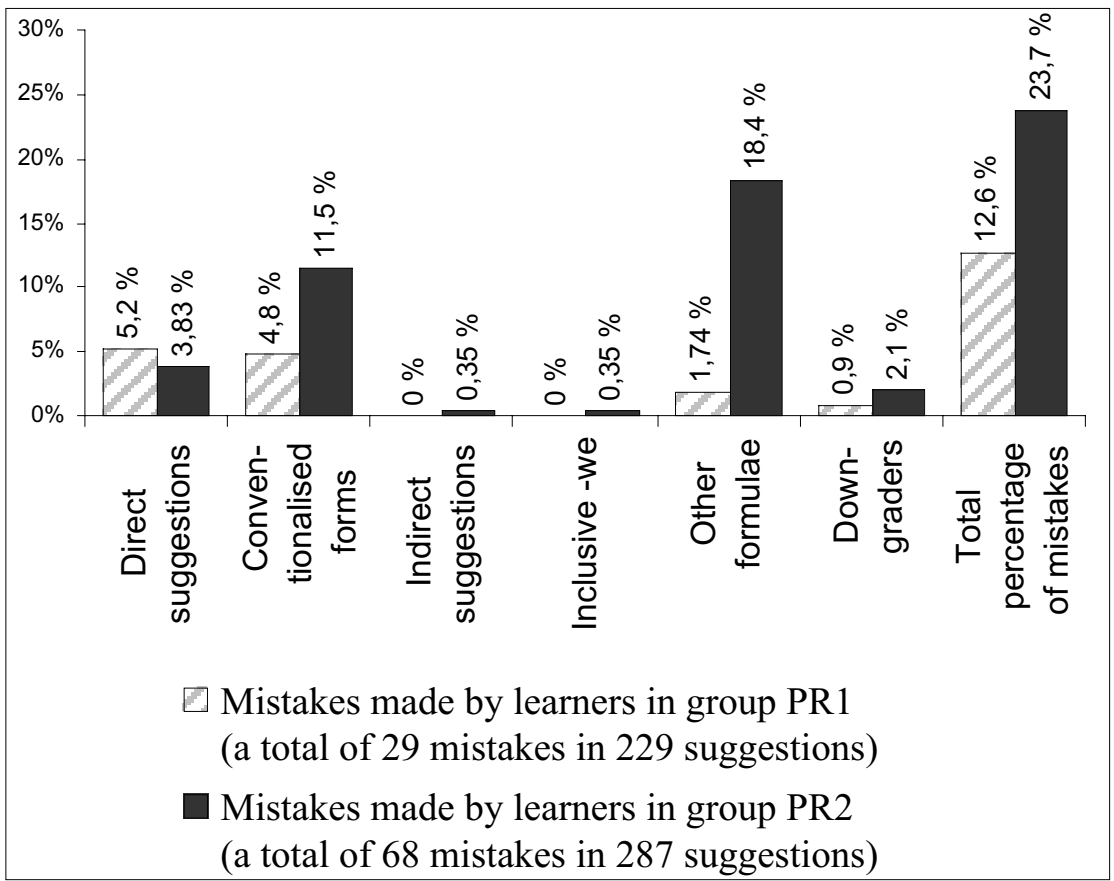

\section{Indirect suggestions}

It is needed more difficult activities.

Inclusive-we

We could write the name of the number.

Other formulae

I think that that they must be do less handouts.

You must use the pronunciation slow.

They had to do pronounce better.

No, I don't want to comment.

I'm nothing suggestion.

Use of downgraders

I think the teacher could to use more...

I think that they must be do ...

The total number of grammatical errors spotted in the suggestions given by group PR1, on the contrary, was very low: they made 12 mistakes in direct suggestions (out of 44), 11 
mistakes in conventionalised forms (out of 69), no mistakes in indirect suggestions, only 4 mistakes in other formulae (out of 57 formulae used), and 2 mistakes in the 57 mitigators they employed. This difference would seem even greater if we take into account that learners in PR1 produced more complex sentences, which may have increased the number of grammatical mistakes they have made in the strategy chosen to suggest. This can be easily perceived if we compare the previous examples with the ones below (once more, some of them coincide with those selected for section 5.1.).

\section{Direct suggestions}

Pay more attention to your writing.

Take care of the pronunciation... Make the lesson more dynamic... And use...

I would recommend that they must improve their body contact.

I guess my suggestion is to speak more.

Conventionalised forms

They could have brought some real food to eat and taught us about it.

If we were they, we would make more dynamic activities....

\section{Indirect suggestions}

It would be more fun using songs, dancing, activities in groups, ...

\section{Inclusive-we}

We would like to suggest that the activities could be more varied and...

Yes, we would do more activities for this lesson.

\section{Other formulae}

We don't know what to say because all the lesson was terrific.

We disapprove of writing a lot for children activity.

I don't hold any particular view on the matter so I can't say.

\section{Use of downgraders}

The way I see it, they could change the dynamics of the activity, the teachers could include more activities.

Maybe they could play a song because kids like it very much.

I think that they should be a little bit more expressive and that....

These results prove our second hypothesis, that is to say, that learners receiving instruction improve their grammatical accuracy when suggesting: after completing the instructional sessions, students in the treatment group produced more elaborate suggesting structures in the activities, which is an obvious sign of the effectiveness of instruction. Nevertheless, when confirming this initial assumption, it is important to take into account that being more grammatically accurate can also be due to the feedback they received. It is also necessary to recognize that mistakes in group PR1 were reduced over the sessions, but only to a very limited extent. This makes us wonder whether students are really aware of teachers' feedback, whether they understand the nature of the mistakes that prompt the feedback, and whether they are able to 
correctly perceive and internalise all the feedback they receive, but these questions go beyond the scope of this paper.

In spite of this concerns, it is worth mentioning that, during the weeks in which students were producing suggestions, their competence was developing progressively, from short or prefabricated phrases, to more complex sentences and different routine formulae. Likewise, we would like to mention learners' perception of explicit instruction on suggestions. Students in group PR1 acknowledged that being instructed on pragmatic appropriateness and grammatical accuracy by means of routine formulae undoubtedly helped them in their production of the speech act. At the same time, they were much more concerned with their grammatical accuracy than with pragmatic knowledge (some of the students even said that knowing how to use the language appropriately, depending on the circumstances, "could not be that important"). Their attitude can be quite understandable: unless their linguistic competence is high, or they experience the importance of pragmatic knowledge, or they see the need for it (if they have to communicate with native speakers, for example), an awareness of pragmatic importance does not develop alone either.

\section{Concluding remarks}

In this paper we have attempted to answer the question of whether teaching pragmatic aspects, such as suggesting, makes a difference in learners' acquisition and use of both their grammatical accuracy and their pragmatic appropriateness, i.e. knowledge of grammatically correct structures and knowledge of when and how to use them. The findings obtained in this empirical study illustrate that learners receiving explicit instruction on how to make suggestions generated more pragmatically appropriate, more varied, more structurally complex, and more correct strategies when suggesting. This may prove that teaching pragmatic aspects can be very effective and beneficial for students in order to develop their pragmatic competence in the target language. It also implies that there is a need to keep analysing what works and what does not work in the FL classroom, to keep on designing more teaching activities that focus on raising learners' awareness of pragmatics, and more tasks which target the grammatical and pragmatic features that are important for learners' communicative competence.

However, our results cannot be extrapolated, because there are many issues that should also be considered: a greater amount of data, and a more thorough and longer instructional period, for instance, could produce very different results. Ways of teaching pragmatics, ways of motivating learners, materials used or type of activities carried out could also make a difference.

For the time being, and as a final remark, we would like to stress that pragmatic knowledge does not seem to come along naturally in EFL classrooms, so we have to contribute to developing learners' pragmatic and linguistic competencies through instruction. In other words: explicit instruction of suggestions may be a good suggestion.

\section{REFERENCES}

Alcón, E. (2000). "The role of conversational interaction in the development of a second language: Its application to English language teaching in the classroom", in Australian Review of Applied Linguistics, 16: 135-154. 
Alcón, E. and Safont, P. (2001). "Occurrence of exhortative speech acts in ELT materials and natural speech data: A focus on request, suggestion and advice realisation strategies", in SELL: Studies in English Language and Linguistics, 3: 5-22.

Banerjee, J. and Carrell, P.L. (1988). "Tuck in your shirt, you squid: Suggestions in ESL", in Language Learning, 38: 313-364.

Bardovi-Harlig, K. (2001). "Evaluating the empirical evidence: Grounds for instruction in pragmatics?", in Rose and Kasper (eds.), Pragmatics in language teaching. Cambridge: CUP, 13-32.

Bardovi-Harlig, K. and Hartford, B.A. (1996). "Input in an institutional setting", in Studies in Second Language Acquisition, 18: 171-188.

Beebe, L.M., Takahashi, T., and Uliss-Weltz, R. (1990). "Pragmatic transfer in ESL refusals", in Scarcela, C., E. Anderson \& D. Krashen (eds.), Developing communicative competence in a second language. New York: Newbury House, 55-73.

Billmyer, K. (1990). "I like your life style: ESL learners learning how to compliment", in Penn Working Papers, 6: 31-48.

Bouton, L.F. (1994). "Can NNS skill in implicatures in American English be improved through explicit instruction?", in Bouton, L.F. (ed.), Pragmatics and language learning monograph series (Vol. 5). Urbana-Champaign: Division of English as an International Language: University of Illinois, 89-109.

Bouton, L.F. (1994). Pragmatics in language teaching. Cambridge: CUP.

Brown, P. and Levinson, S. (1987). Politeness: Some universals in language use. Cambridge: Cambridge University Press.

Celce-Murcia, M., Dörnyei, Z., and Thurrell, S. (1995). "Communicative competence: A pedagogically motivated model with content specifications", in Issues in Applied Linguistics, 6: 5-35.

Fukuya, Y.J. and Clark, M.K. (2001). "A comparison of input enhancement and explicit instruction of mitigators", in Bouton, L.F. (ed.), Pragmatics and language learning monograph series (Vol. 10). Urbana-Champaign: Division of English as an International Language: University of Illinois, 111-130.

Fukuya, Y.J. and Zhang, Y. (2002). "Effects of recasts on EFL learners' acquisition of pragmalinguistic conventions of request", in Second Language Studies, 21: 1-47.

Fukuya, Y.J. et al. (1998). Does focus on form work for teaching sociopragmatics, in ERIC Document Reproduction Service No. ED 452736.

Haverkate, H. (1984). Speech Acts, Speakers and Hearers. Amsterdam: John Benjamin Publishing Company.

Hinkel, E. (1994). “Appropriateness of advice as L2 solidarity strategy”, in RELC Journal, 25: 7193.

Hinkel, E. (1997). “Appropriateness of Advice: DCT and Multiple Choice Data”, in Applied Linguistics, 18: 1-26.

House, J. (1996). "Developing pragmatic fluency in English as a foreign language: Routines and metapragmatic awareness", in Studies in Second Language Acquisition, 18: 225-252.

House, J. and Kasper, G. (1981). Zur Rolle der Kognition in Kommunicationskursen, in Die Neueren Sprachen, 80: 42-55.

Judd, E.L. (1999). "Some issues in the teaching of pragmatic competence", in Hinkel, E. (ed.) Culture in second language teaching and learning. Cambridge: Cambridge University Press, $152-166$

Kasper, G. (1997). “Can pragmatic competence be taught?” [URL: http://nflrc.hawaii.edu/ NetWorks/ NW06/default.html].

Kasper, G. (2001a). "Learning pragmatics in the L2 classroom", in Bouton, L.F. (ed.) Pragmatics 
and language learning monograph series, vol. 10. Urbana, IL: University of Illinois at Urbana-Champaign.

Kasper, G. (2001b). "Classroom research in interlanguage pragmatics", in Rose and Kasper (eds.), Pragmatics in language teaching. Cambridge: CUP, 33-60.

Kasper, G. and Rose, K.R. (eds.) (2002). Pragmatics in language teaching. Cambridge: Cambridge University Press.

Kasper, G. and Schmidt, R. (1996). "Developmental issues in interlanguage pragmatics", in Studies in second language acquisition, 18: 149-169.

Koester, A. (2002). "The performance of speech acts in workplace conversations and the teaching of communicative functions", in System, 30: 167-184.

Koike, D. (1994). "Negation in Spanish and English suggestions and requests: Mitigating effects?", in Journal of Pragmatics, 21: 513-526.

Koike, D. (1996). "Transfer of pragmatic competence and suggestions in Spanish foreign language learning", in S. M. Gass and J. Neu (eds.) Speech acts across cultures. Berlin: Mouton de Gruyter, 257-281.

Kubota, M. (1995). "Teachability of conversational implicatures to Japanese EFL learners", in Institute of Research in Language Teaching Bulletin, 9: 35-67.

Liddicoat, A.J., and Crozet, C. (2001). "Acquiring French interactional norms through instruction", in Rose and Kasper (eds.), Pragmatics in language teaching. Cambridge: CUP, 125-144.

LoCastro, V. (1997). "Pedagogical intervention and pragmatic competence development", in Applied Language Learning, 8: 75-109.

Lyster, R. (1994). "The effects of functional-analytical teaching on aspects of French immersion students' sociolinguistic competence", in Applied Linguistics, 15: 263-287.

Mandala, S. (1999). "Exiting advice", in L. F. Bouton (ed.) Pragmatics and language learning, vol. 9. Urbana, IL: University of Illinois at Urbana-Champaign, 89-111.

Martínez-Flor, A. (2004). The effect of instruction on the development of pragmatic competence in the English as a foreign language context: A study based on suggestions. Doctoral Dissertation. Castellón: Universitat Jaume I.

Martínez-Flor, A. and Fernández Guerra, A. (Forthcoming). "Collaborative discourse and teachers' feedback in the EFL classroom: the case of suggestions", in Esteve, M.J. et al. (eds.), English language teaching and learning from a discoursive perspective. Castellón: Publicacions de la Universitat Jaume I.

Martínez-Flor, A., Usó Juan, E. and Fernández Guerra, A. (eds.) (2003). Pragmatic competence and foreign language teaching. Castellón: Universitat Jaume I.

Morrow, C.K. (1995). The pragmatic effects of instruction on ESL learners' production of complaint and refusal speech acts. Unpublished doctoral dissertation. Buffalo: State University of New York.

Norris, J. and Ortega, L. (2000). "Effectiveness of L2 instruction: A research synthesis and quantitative meta-analysis", in Language Learning, 50: 417-528.

Olshtain, E. and Cohen, A.D. (1990). "The learning of complex speech act behavior", in TESL Canada Journal, 7: 45-65.

Olshtain, E. and Cohen, A.D. (1991). "Teaching speech act behavior to nonnative speakers", in Celce-Murcia (ed.), Teaching English as a second and foreign language. Boston: Heinle \& Heinle, 167-180.

Rose, K. and Kasper, G. (eds.) (2001). Pragmatics in language teaching. Cambridge: Cambridge University Press.

Rose, K. and Ng Kwain-fun, C. (2001). "Inductive and deductive teaching of compliments and compliment responses", in Rose and Kasper (eds.), Pragmatics in language teaching. Cambridge: CUP, 145-170. 
Safont, P. (2001). Meta-pragmatic perspectives on L3 Acquisition: Analysing Requests in the EAP Context. Unpublished doctoral dissertation. Castellón: Universitat Jaume I.

Safont, P. (2003). "Instructional effects on the use of request acts modification devices by EFL learners". In Martínez-Flor, Usó Juan and Fernández Guerra (eds.), Pragmatic competence and foreign language teaching. Castellón: Universitat Jaume I, 211-232.

Salazar, P. (2003). "Pragmatic instruction in the EFL context". In Martínez-Flor, Usó Juan and Fernández Guerra (eds.), Pragmatic competence and foreign language teaching. Castellón: Universitat Jaume I, 233-246.

Schmidt, R., Shimura, A., Wang, Z. and Jeong, H. (1996). "Suggestions to buy: Television commercials from the U.S., Japan, China, and Korea", in Gass, S.M. and Neu, J. (eds.), Speech acts across cultures. Berlin: Mouton de Gruyter.

Shaw, P. and Trosborg, A. (2000). "Sorry does not pay my bills: customer complaints in a cross cultural setting", in Lynch, D. and Pilbeam, A. (eds.), Heritage and progress. From the past to the future in intercultural understanding. Bath: UK, LTS Training and Consulting in association with SIETAR Europa, 204-214.

Takahashi, S. (2001). "The role of input enhancement in developing pragmatic competence". In Rose and Kasper (eds.), Pragmatics in language teaching. Cambridge: CUP, 125-144.

Tateyama, Y. (2001). "Explicit and implicit teaching of pragmatic routines: Japanese 'sumimasen'”. In Rose and Kasper (eds.), Pragmatics in language teaching. Cambridge: CUP, 200-222.

Tateyama, Y. et al. (1997). "Explicit and implicit teaching of pragmatic routines", in Bouton (ed.), "Can NNS skill in implicatures in American English be improved through explicit instruction?".

Thomas, J. (1983). "Cross-cultural pragmatic failure", in Applied Linguistics, 4: 91-112.

Wardhaugh, R. (1985). How Conversation Works. Cambridge, MA: Basil Blackwell.

Wildner-Bassett, M.E. (1984). Improving pragmatic aspects of learners' interlanguage. Tübingen: Gunter Narr Verlag.

Wildner-Bassett, M.E. (1986). "Teaching and learning "Polite Noises", in Improving pragmatic aspects of advanced adult learners' interlanguage”. In Kasper, G. (ed.), Learning, teaching and communication in the foreign language classroom. Aarhus: Aarhus University Press, 163-178.

Wildner-Bassett, M.E. (1994). "Intercultural pragmatics and proficiency: Polite 'noises' for cultural appropriateness", in IRAL, 32: 3-17.

Wishnoff, J. (2000). "Hedging your bets: L2 learners' acquisition of pragmatic devices in academic writing and computer-mediated discourse", in Working Papers of the Department of ESL, 19.

Yoshimi, D.R. (2001). "Explicit instruction and JFL learners' use of interactional discourse markers", in Rose and Kasper (eds.), Pragmatics in language teaching. Cambridge: CUP, 223-247. 